\title{
ARES I-X LAUNCH VEHICLE MODAL TEST MEASUREMENTS AND DATA QUALITY ASSESSMENTS
}

\author{
J. D. Templeton, R. D. Buehrle and J. L. Gaspar \\ NASA Langley Research Center \\ Hampton, VA \\ R. A. Parks and D. R. Lazor \\ NASA Marshall Space Flight Center \\ Huntsville, AL
}

\begin{abstract}
The Ares I-X modal test program consisted of three modal tests conducted at the Vehicle Assembly Building at NASA's Kennedy Space Center. The first test was performed on the 71-foot 53,000-pound top segment of the Ares I-X launch vehicle known as Super Stack 5 and the second test was performed on the 66-foot 146,000-pound middle segment known as Super Stack 1. For these tests, two $250 \mathrm{lb}$-peak electro-dynamic shakers were used to excite bending and shell modes with the test articles resting on the floor. The third modal test was performed on the 327-foot 1,800,000-pound Ares I-X launch vehicle mounted to the Mobile Launcher Platform. The excitation for this test consisted of four $1000+\mathrm{lb}$-peak hydraulic shakers arranged to excite the vehicle's cantilevered bending modes. Because the frequencies of interest for these modal tests ranged from 0.02 to $30 \mathrm{~Hz}$, high sensitivity capacitive accelerometers were used. Excitation techniques included impact, burst random, pure random, and force controlled sine sweep. This paper provides the test details for the companion papers covering the Ares I-X finite element model calibration process. Topics to be discussed include test setups, procedures, measurements, data quality assessments, and consistency of modal parameter estimates.
\end{abstract}

\section{INTRODUCTION}

The Ares I-X launch vehicle is the first flight test vehicle for the Ares I launch vehicle, which is intended to be NASA's replacement for the Space Shuttle. Ares I-X consists of a 4 segment solid rocket motor with mass simulated hardware attached. The 4 segment solid rocket motor is the type that is typically used to assemble and launch the Space Shuttle. Because the Ares I vehicle will use a 5 segment solid rocket motor, the lowest set of mass simulated hardware was a dummy $5^{\text {th }}$ segment. Above this hardware, the rest of the vehicle consisted of interstage and upper stage hardware that was not be recovered during the flight test. The upper stage consisted of a series of segments with internal platforms to provide access up to the top of the launch vehicle. At the top of the launch vehicle was the mass simulated hardware for the Crew Module and Launch Abort System (CM/LAS). The entire launch vehicle was assembled in the Vehicle Assembly Building of NASA Kennedy Space Center atop a Mobile Launcher Platform, as shown in Figure 1. Ares I-X was successfully launched on October $28^{\text {th }}, 2009$.

A series of three modal tests were performed on Ares I-X hardware from May through August 2009. These modal tests were intended to calibrate a finite element model so that the first three free-free bending mode pairs of the Ares I-X launch vehicle could be accurately predicted. The free-free modes would then be compared to the modal parameters used in flight control system evaluations to ensure the robustness of the control system design. Based on the free-free modes of interest, the target test modes were identified using pre-test analysis'. The target test modes for the flight test vehicle on the Mobile Launcher Platform were the first four bending mode pairs. In order to reduce the uncertainty in the finite element model before the flight test vehicle modal test, two component level modal tests were also proposed. The first of these modal tests was performed on the topmost hardware of the launch vehicle known as Super Stack 5, and the second was performed on the $5^{\text {th }}$ segment and interstage hardware at the middle of the launch vehicle known as Super Stack 1. This paper will focus primarily on the modal test of the fully assembled Ares I-X launch vehicle, although all of the modal test setups will be discussed. 


\section{TEST SETUPS}

The modal test of the fully assembled Ares I-X launch vehicle mounted on the Mobile Launcher Platform was known as the Flight Test Vehicle modal test. The instrumentation used for this modal test consisted of 90 PCB series 3701 capacitive accelerometers with $1 \mathrm{~V} / \mathrm{g}$ sensitivity that were placed at 40 locations on the launch vehicle and Mobile Launcher Platform. Of these 40 acceleration measurement locations, 19 were arranged in a triaxial configuration, 12 were biaxial, and 9 were uniaxial, as shown in Figure 2 below. The instrumentation locations were selected based on pre-test analysis ${ }^{1}$ so that the first four bending mode pairs could be measured and distinguished from torsion modes and system modes with Mobile Launcher Platform participation. In addition to the acceleration measurements, one strain gage bridge was measured at each of the four hold down posts where the launch vehicle was bolted to the Mobile Launcher Platform. Additional strain gage bridge measurements at the hold down posts were also acquired during the modal test on a separate data acquisition system.

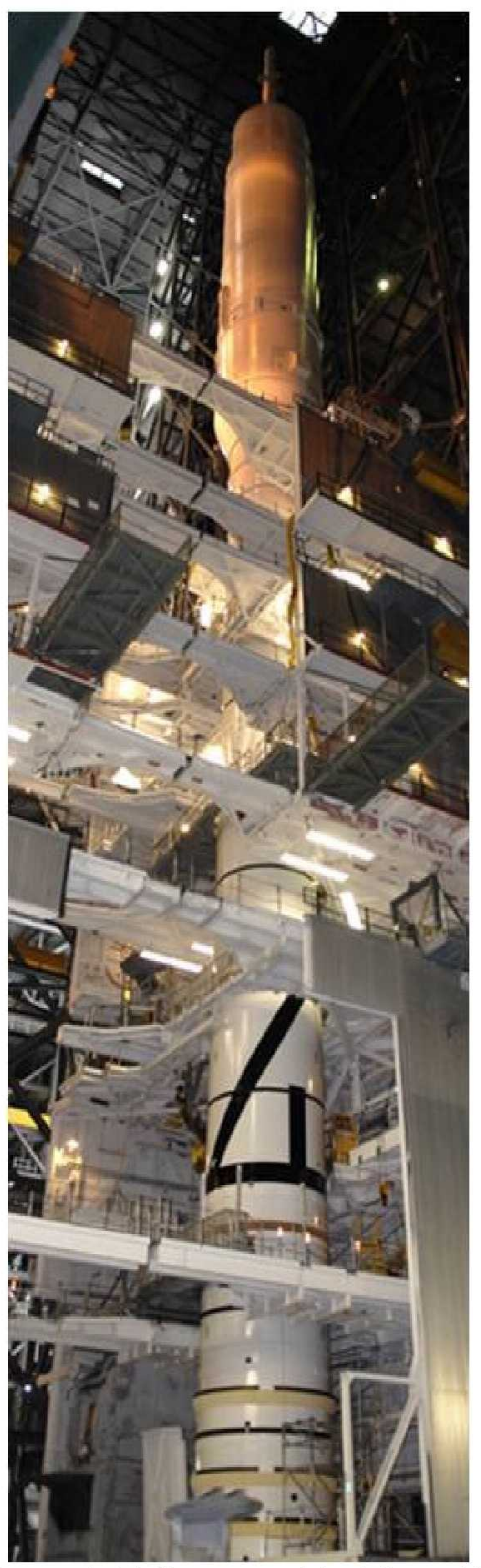

Figure 1. Fully assembled Ares I-X launch vehicle ${ }^{2}$

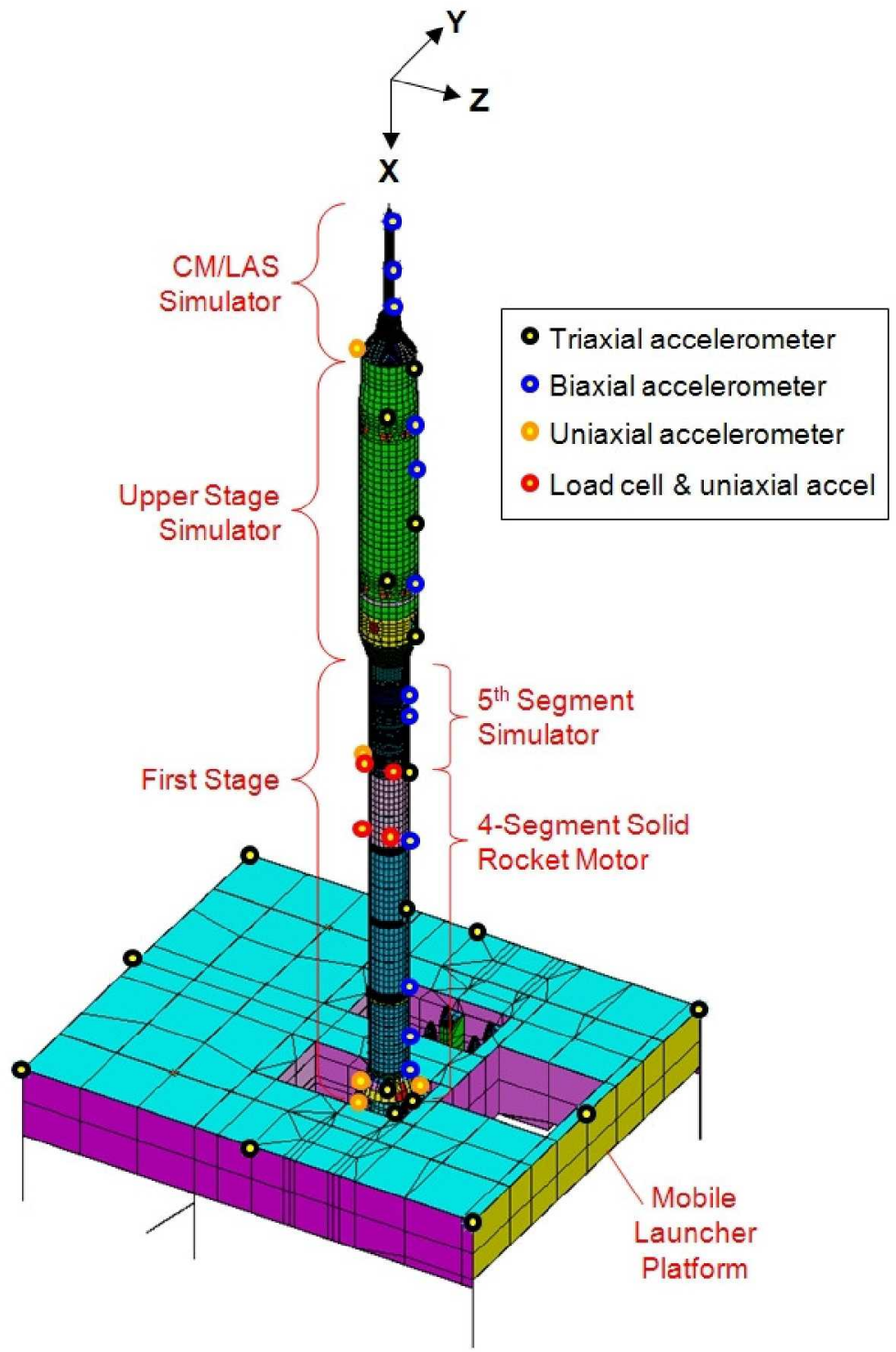

Figure 2. Flight test vehicle modal test instrumentation locations 
The primary method of excitation for the flight test vehicle modal test used four hydraulic shaker systems with a dynamic force capability of $1560 \mathrm{lb}$-peak and dynamic stroke of 2 in-peak. Due to safety concerns, the actual dynamic force capability available during the test was $560 \mathrm{lb}$-peak due to a lowered operating pressure. These systems consisted of components manufactured by the Team Corporation. The hydraulic shaker actuators were attached to a mounting frame that allowed the actuator to slide linearly on two hydraulic cylinders with adjustable stiffness as shown in Figure 3. Each shaker was mounted to two existing holes in work platforms through the front I-beam of the mounting frame, and $600 \mathrm{lb}$ of additional weight was added to the rear of the mounting frame to improve the force input to the flight test vehicle. Each hydraulic actuator was connected to the vehicle through the use of a $1 / 2$ " threaded rod connected to a PCB series 223 dynamic load cell mounted to an 8 " square aluminum plate, which was attached to the vehicle using Tridox F88 dental cement. An additional static load cell was mounted on the actuator side of the threaded rod to monitor static load inputs. Although the actuators were designed to allow linear movement on the mounting frame, they were operated during the modal test with an additional solenoid active to increase the rigidity of the actuator relative to the work platform. The hydraulic power supplies and solenoids were controlled remotely at a location near the data acquisition system. Team model 2240 valve drivers were used at this location to control the shakers based on Linear Variable Differential Transformer position feedback from each shaker and an input signal from the data acquisition system. The shaker systems were located on two work platforms near the $4^{\text {th }}$ and $5^{\text {th }}$ segments of the flight test vehicle's first stage. Pre-test analysis showed that these locations were able to excite all modes of interest and that the highest chosen platform was an optimal location for exciting the $2^{\text {nd }}$ through $4^{\text {th }}$ bending modes. On each work platform, the shakers were oriented at $45^{\circ}$ to the preferred direction of travel of the vehicle and $90^{\circ}$ relative to each other. This was necessary in order to avoid flight test instrumentation cables and equipment attached to the vehicle while still maintaining an orthogonal shaker setup.

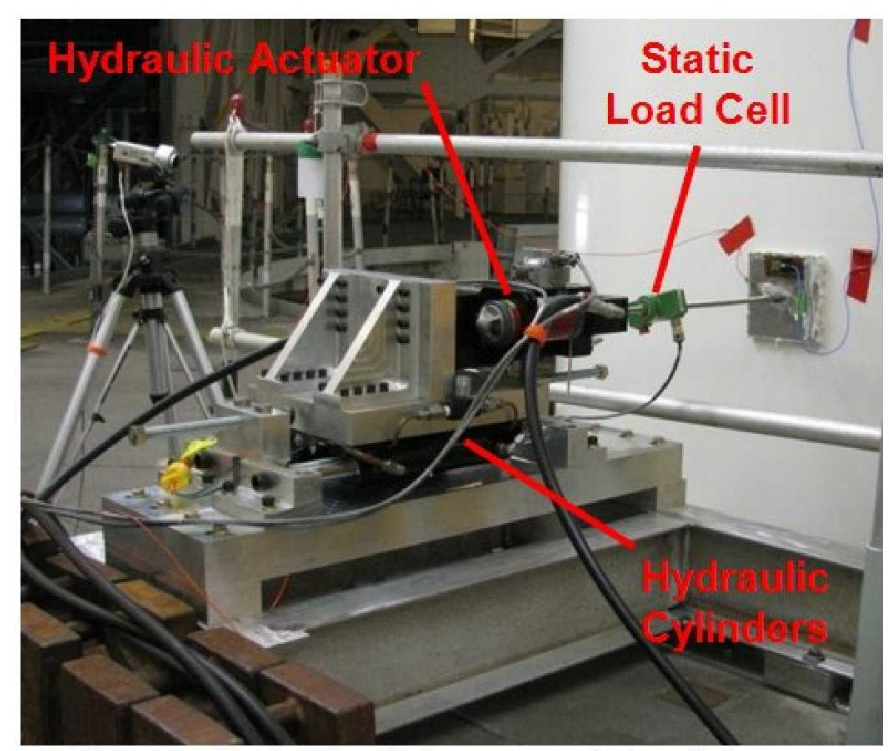

Figure 3. Hydraulic shaker setup during flight test vehicle modal test

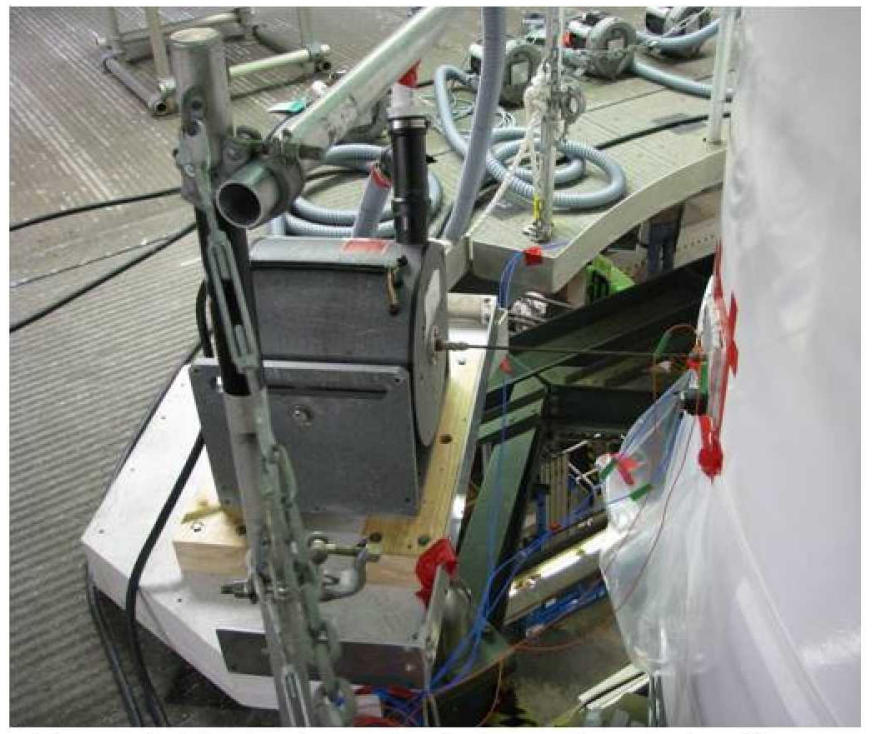

Figure 4. Electrodynamic shaker setup during Super Stack 1 modal test

The data acquisition system for the modal tests consisted of VXI Technology model VT1432B 24-bit digitizer cards and a Hewlett Packard model 1434A source card in a single Agilent Technologies model E8403A 13-slot mainframe. These data acquisition and source cards were controlled through a Firewire connection to a data acquisition computer running $m+p$ International SmartOffice Analyzer software. The software allowed time history throughput data to be recorded directly to disk while simultaneously computing, displaying and storing autopower, coherence, and frequency response functions during testing.

The Super Stack 5 modal test setup consisted of the top portion of the flight test vehicle bolted to a Super Segment Assembly Stand and heavy weight Upper Stage Simulator transportation cart that rested on a concrete floor, as shown in Figure 5. Test instrumentation consisted of 70 accelerometers placed at 30 locations on the test article in order to measure the first three bending mode pairs of the stack. Of these 30 locations, 10 were arranged in a triaxial configuration and 20 were biaxial. This test used two MB Dynamics model 250 electrodynamic shakers for excitation of the vehicle, shown in Figure 4. Each shaker had a 2" stroke and was capable of 
providing $250 \mathrm{lb}$-peak force with supplemental forced air cooling. The shakers for this test were mounted to wooden pallets that were lifted to a height of approximately 16 feet by JLG telehandlers. The shaker locations were identified by the pre-test analysis as optimal locations within elevation constraints imposed by the project. The force input spectra to the structure remained flat with no significant dips, and additional triaxial accelerometers mounted to the shakers showed that the telehandler modal frequencies were not at the target modal frequencies. Impact testing at the shaker input locations also showed that the frequency response functions were consistent with those acquired using the shakers. These checks were performed both as a pretest step on another structure and during the actual test to verify that the chosen shaker setup was acceptable.

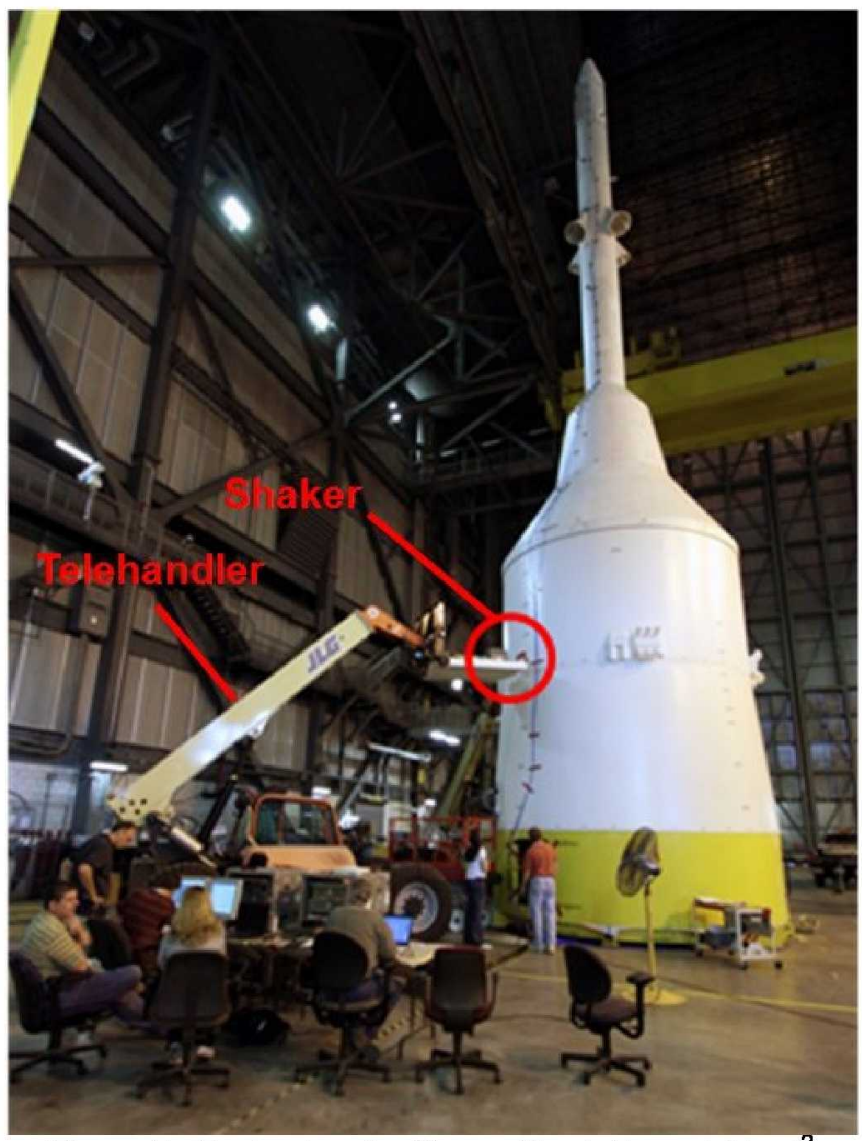

Figure 5. Test setup for Super Stack 5 modal test ${ }^{2}$

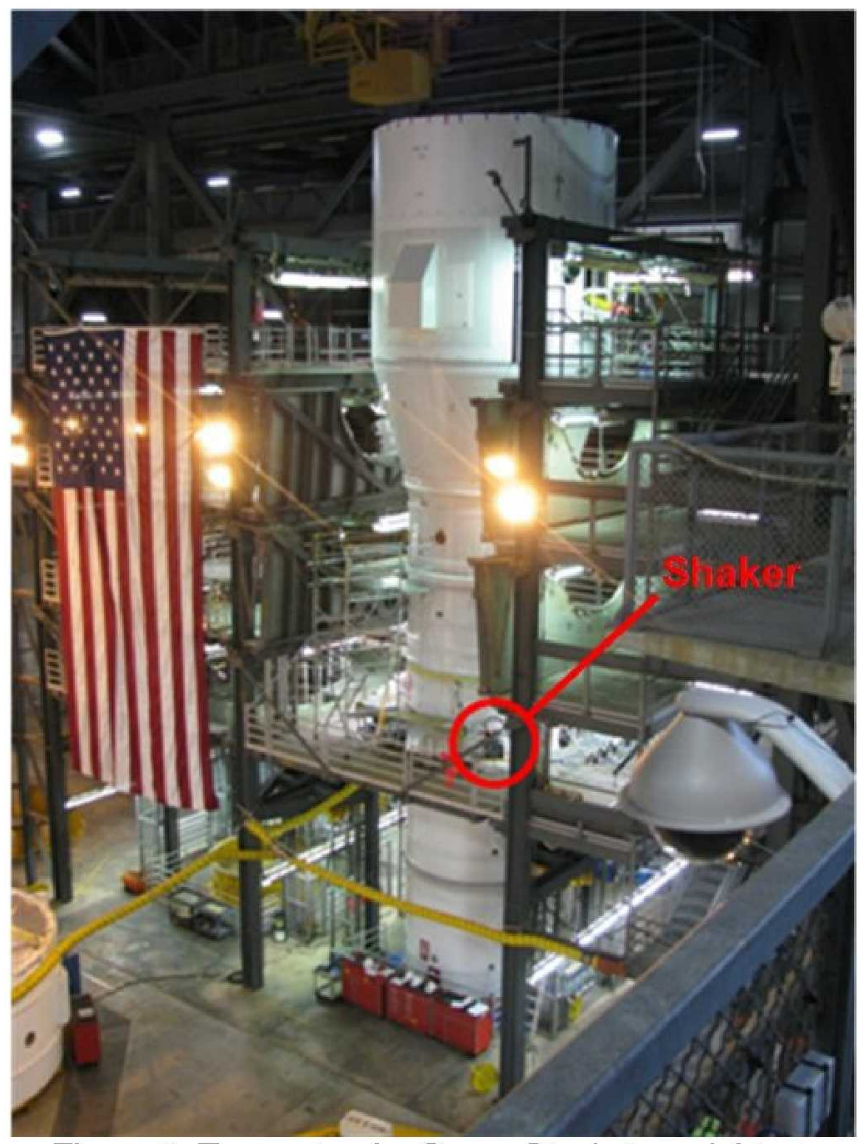

Figure 6. Test setup for Super Stack 1 modal test

The Super Stack 1 modal test setup consisted of the $5^{\text {th }}$ segment and interstage components in a buildup stand shown in Figure 6. Project constraints resulted in the Super Stack 1 segment being tested while resting on 12 steel shims on an I-beam support structure on top of reinforced concrete pylons. Instrumentation was located at 45 locations, with 7 triaxial, 29 biaxial, and 9 uniaxial locations, totaling 88 accelerometers. The same $250 \mathrm{lb}-$ peak electro-dynamic shakers from the Super Stack 5 test were used for this test, and they were located on a work platform near the middle of the stack. The shaker locations were influenced by project constraints, and pretest analysis confirmed that the locations were satisfactory for exciting the modes of interest. The shakers were lag bolted to wooden fixtures to simplify alignment procedures, and these fixtures were bolted to the work platform in 2 locations near the front of the shaker, as shown in Figure 4.

\section{TEST EXECUTION}

The test execution for all three tests was similar, so only the flight test vehicle test will be described to demonstrate the process. More information on the test execution for the Super Stack 5 and Super Stack 1 modal tests are included in NASA technical memorandums $\mathbf{s}^{3,4,5}$. 
The flight test vehicle modal test data was acquired over the course of 3 test days. The vehicle was clear of personnel during testing on these days. A summary of the high quality datasets that were acquired during this time is given in Table 1.

Table 1. Flight Test Vehicle Modal Test Data Summary

\begin{tabular}{|c|c|c|c|c|c|}
\hline Type & Quantity & Force Levels & Frequency Range & Resolution & Averages \\
\hline Ambient Noise & 2 & $\mathrm{n} / \mathrm{a}$ & $0-12.5 \mathrm{~Hz}$ & $0.0019 \mathrm{~Hz}$ & 23 \\
\hline Random & 3 & $50,130,200 \mathrm{lb}-\mathrm{rms}$ & $0-6.0 / 12.5 \mathrm{~Hz}$ & $0.0019 \mathrm{~Hz}$ & 23 \\
\hline Sine Sweep & 9 & $50,100,200 \mathrm{lb}-$ peak & Mode Dependent & Mode Dependent & 1 \\
\hline Free Decay & 7 & $\mathrm{n} / \mathrm{a}$ & Time Data & 0.031 seconds & $\mathrm{n} / \mathrm{a}$ \\
\hline Tap Test & 11 & $50-800 \mathrm{lb}-$ peak & $0-200 / 400 \mathrm{~Hz}$ & $0.125 \mathrm{~Hz}$ & $\mathbf{8}$ \\
\hline
\end{tabular}

The first datasets to be acquired were the two ambient noise tests. This test data was actually acquired during the test setup days, while people were still working inside and outside the vehicle. During one dataset the high bay doors were left open and wind loads were exciting the vehicle bending modes. This data was sampled at $16 \mathrm{~Hz}$ with a block size of 512 seconds (8.5 minutes) to achieve the desired resolution of $0.0019 \mathrm{~Hz}$.

Autopower data was processed with a Hanning window and a $50 \%$ overlap, and 23 averages were acquired for a total test time of 1 hour and 42 minutes.

Acquisition of the 3 random datasets used similar parameters to the ambient noise tests, but frequency response functions and multiple coherence functions were processed from the data in addition to the autopower. The frequency response functions were computed during acquisition using the $\mathrm{H} 1$ estimator. During all but the $200 \mathrm{lb}$-rms random dataset, 4 shakers were operational and a bandwidth of $12.5 \mathrm{~Hz}$ was used for the force input. In order to focus more energy into the target modes, a bandwidth of $6.0 \mathrm{~Hz}$ was used for the $200 \mathrm{lb}$-rms random test, but the failure of an analog filter on one of the shaker source channels caused only 3 shakers to be operational.

Selection of the resolution for the ambient noise and random datasets was a function of both the desired data quality and the limited test time available. The desired resolution was based on a "rule of thumb" suggested by Elliott and Richardson ${ }^{6}$ that " 5 or more samples above the 6-dB points, or the noise floor, of a resonance peak is considered acceptable for good curve fitting." Based upon this rule, the predicted natural frequencies, and an assumed damping of $0.5 \%$, a block size of 34 minutes was determined to be required for a good curve fit of the $1^{\text {st }}$ bending modes. This can be seen in Figure 7, where the measured modal frequencies and damping values are plotted on a chart that was generated numerically (the predicted frequencies for these modes were very close to the measured frequencies). Unfortunately, the 34 minute block would have resulted in unacceptable test times, so the 8.5 minute block was selected based upon the $2^{\text {nd }}$ bending modes. The strategy for the $1^{\text {st }}$ bending modes was to reprocess the data from the time histories so that the desired resolution could be achieved with fewer averages. Previous testing of Super Stacks 1 and 5 had indicated that 20 averages provided acceptable test results, so the plan was to acquire $12 \times 8.5$ minute blocks, and process them to 23 averages with $50 \%$ overlap. If the initial curve fit of the first random dataset was unacceptable, the time records could be increased in later random tests. 


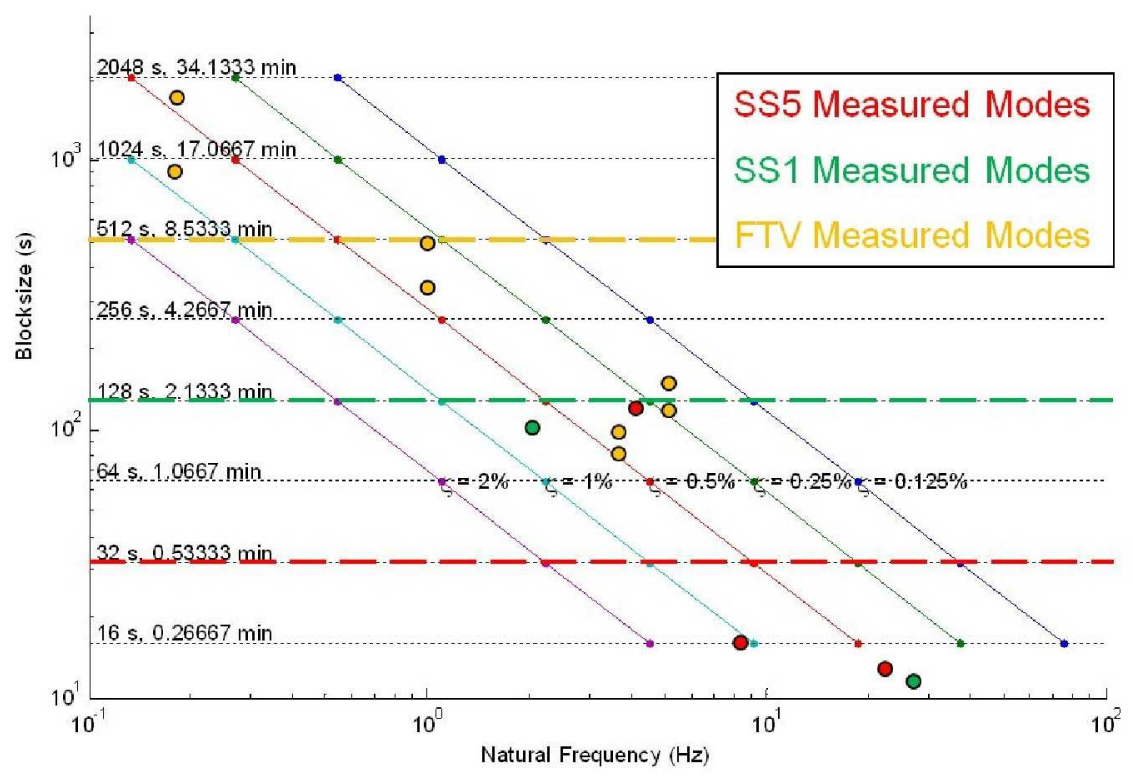

Figure 7. Chart of desired block size versus natural frequency for various damping values

The sine sweep tests were performed with a single shaker and focused on exciting the $2^{\text {nd }}$ and $3^{\text {rd }}$ bending modes at various force levels as a linearity study. Because the shakers were mounted at $45^{\circ}$ to the preferred direction of each mode, a single shaker could excite the modes in both axes. For the $2^{\text {nd }}$ bending modes, a lower platform shaker was used for excitation, and an upper platform shaker was used for the $3^{\text {rd }}$ bending modes. This was because the node locations of the $3^{\text {rd }}$ bending modes were very close to the lower shaker platform. The $2^{\text {nd }}$ bending modes had similar mode shape magnitudes at either platform, so the lower shaker was chosen for easy observation from the data acquisition system. The sweep rate was chosen based on natural frequency and damping ratios identified during a random test according to an equation listed in Modal Testing by Ewins ${ }^{7}$.

$$
S_{\max }<310\left(f_{r}\right)\left(\zeta_{r}\right)^{2} \text { octaves } / \min
$$

The resulting sweep rates were 0.003 octaves per minute for the $2^{\text {nd }}$ bending mode pair, and 0.01 octaves per minute for the $3^{\text {rd }}$ bending mode pair. The force was controlled to a constant level during the sine sweeps by the $m+p$ SmartOffice software, but the lowest sweep rate that our version of the software would allow was 0.01 octaves per minute. This was one of the consequences of lower than expected damping values. In order to work around this situation, the plan was to sweep at the 0.01 octaves per minute rate with the knowledge that only about $80 \%$ of the steady state response would be reached during the sweeps of the $2^{\text {nd }}$ bending modes ${ }^{8}$.

During the first sine sweep attempts on the $2^{\text {nd }}$ bending modes, an issue occurred where the force level went unstable after passing through the resonance and nearly doubled in force. The cause of this issue has not been identified. In order to work around this problem, the sine sweeps were stopped as soon as the force level went unstable. The force instability for sweeps of these modes occurred after passing the $6 \mathrm{~dB}$ points, so the data was still considered to be acceptable. This instability was not a problem during the sweeps on the $3^{\text {rd }}$ bending modes, so the $3^{\text {rd }}$ bending mode sweeps excited modes in both axes during a single sweep.

In order to investigate the damping linearity of the $1^{\text {st }}$ bending modes, several free decay tests were performed on the flight test vehicle. From the top work platforms next to the vehicle, several members of the test team pushed on the vehicle in synchronization with the first bending mode period, approximately every 5 seconds. The vehicle eventually responded with approximately 8 " deflections at the top of the vehicle, which was the maximum deflection that could be safely reached while maintaining acceptable platform clearances. When the maximum deflection was reached, the vehicle motion was allowed to decay naturally. The resulting time history data allowed the damping to be estimated using a logarithmic decrement approach. One more free decay test was also performed in an attempt to target the $2^{\text {nd }}$ bending mode in the $Y$-direction. The raw acceleration responses from this test did not clearly indicate individual peaks, but band-pass filtering did allow this data to be used to estimate damping as well. 
The final set of tests that were performed on the vehicle were tap tests with a $3 \mathrm{lb}$ instrumented hammer. The tap tests were intended to investigate local modes near three instrumentation locations for the Guidance, Navigation and Control system. These tap tests had a wider frequency bandwidth of excitation than the shaker tests.

\section{RESULTS AND DISCUSSION}

Only the flight test vehicle results will are provided in this section. A companion paper ${ }^{9}$ will provide a short overview of the measured mode shapes from all of the Ares I-X modal tests and their use in model calibration. More information on the test results for the Super Stack 5 and Super Stack 1 modal tests are included in NASA technical memorandums $\mathbf{s}^{3,4,5}$.

Sample frequency response data from the $130 \mathrm{lb}$-rms random dataset is shown in Figure 8 below. The plot shows that the peaks corresponding to the $2^{\text {nd }}$ through $4^{\text {th }}$ bending mode pairs are clearly defined with minor coherence drops at the peaks of the $2^{\text {nd }}$ bending modes. The $1^{\text {st }}$ bending mode pair, however, had large coherence drops where the peaks were split in half, as shown in Figure 9. Methods were sought to improve the coherence near these peaks, such as the use of load cell signal conditioners that had a lower frequency response and acquisition of unconditioned Integrated Electronics Piezo Electric (IEPE) signals from the load cells. Neither of these methods resulted in improved low frequency coherence. The cause of these drops in coherence is unknown but thought to be related to the locations of the shakers and the ambient movement of the structure. An alternative explanation is related to the fact that the hermetic seals of the load cells may have been breached in a previous modification, possibly changing the time constant of the circuit. The peaks in the autopower from the ambient noise tests were clearly defined and did not show this split. Due to this difficulty in exciting the $1^{\text {st }}$ bending mode, frequency and damping estimates were acquired using free-decay response measurements.

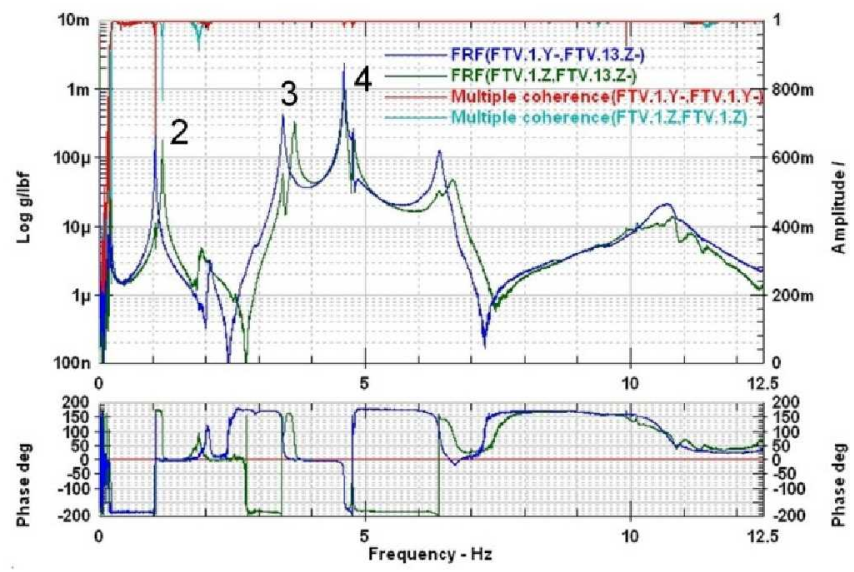

Figure 8. Frequency response functions and multiple coherence functions from flight test vehicle random test

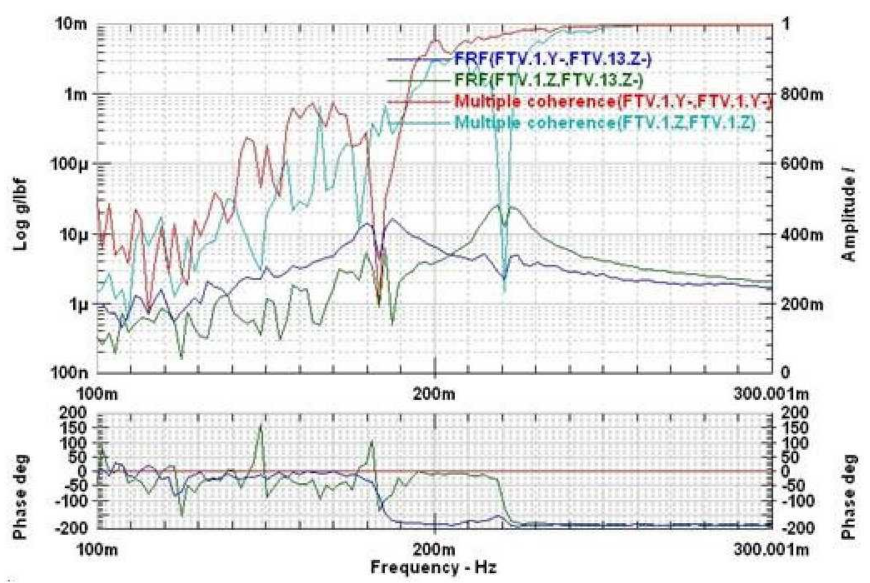

Figure 9. Detailed view of split peaks in frequency response functions

Another interesting phenomenon from the random datasets was the peaks that showed up in the load cell autopower data as shown in Figure 10. These peaks did not correspond to any of the peak response frequencies identified in the frequency response functions. The load cell spectra were otherwise flat across the bandwidth of interest.

Good reciprocity was exhibited for all cases in all of the random test datasets. A sample comparison between the upper platform shakers for the $130 \mathrm{lb}$-rms dataset is shown in Figure 11. 


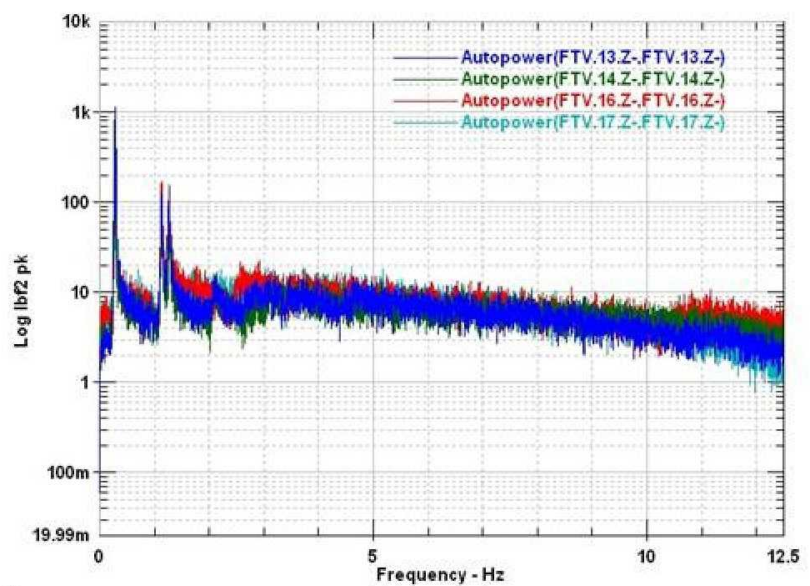

Figure 10. Load cell autopower measurements from flight test vehicle random test

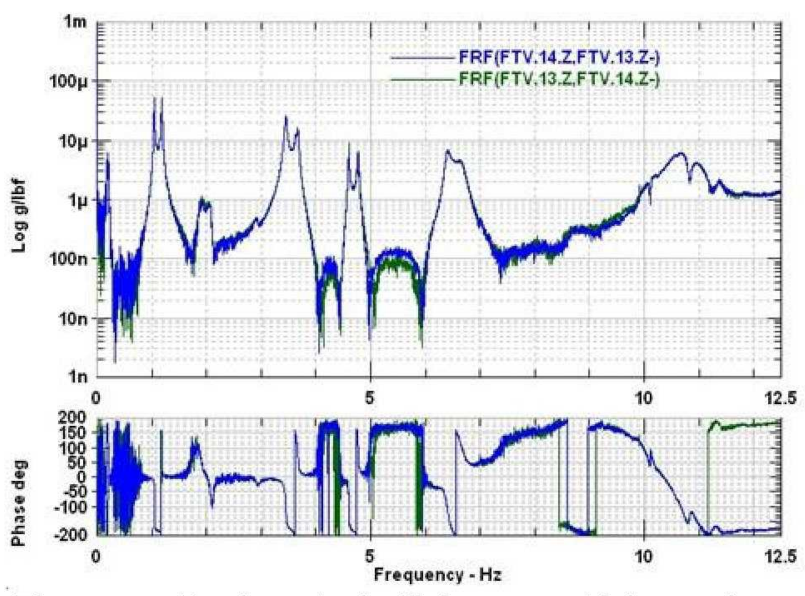

Figure 11. Reciprocity in flight test vehicle random test data

A comparison of the same frequency response function measurements from the three random tests shows that the target bending modes were linear for the tested excitation levels. A system level mode that included movement of the Mobile Launcher Platform did indicate some nonlinearity, but this was not a problem because it was not a target mode for the test. The peak frequencies of the $2^{\text {nd }}$ through $4^{\text {th }}$ bending modes from these random tests are shown in Table 2. The table indicates that frequency shifts were all below $1 \%$ from 50 to $200 \mathrm{lb}$ rms. The $2^{\text {nd }}$ bending mode in the Z-direction had the greatest frequency shift at $0.82 \%$, while the other bending modes did not shift by more than $0.34 \%$.

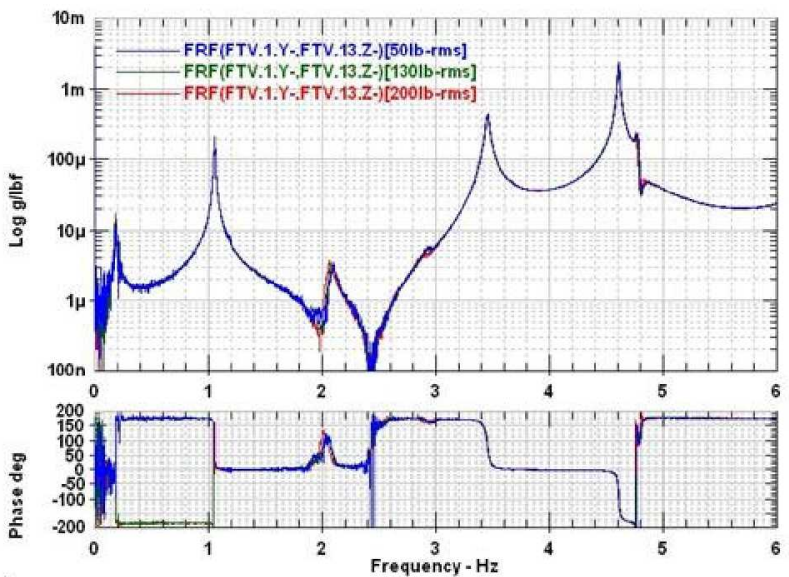

Figure 12. Linearity of Y-direction frequency response functions from flight test vehicle random tests

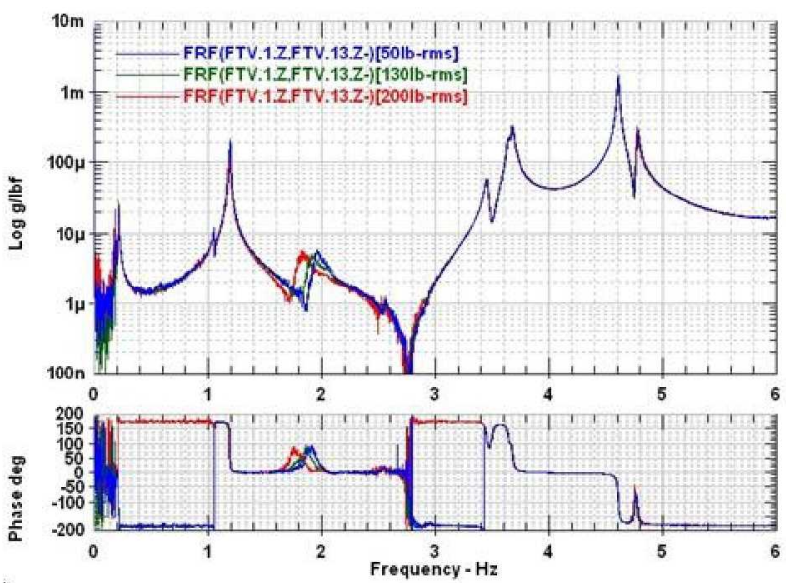

Figure 13. Linearity of Z-direction frequency response functions from flight test vehicle random tests

Table 2. Peak Frequency Changes for Random Excitation

\begin{tabular}{|l|c|c|c|c|}
\hline Mode & $\begin{array}{c}\text { Random } \\
\text { 50 Ib-rms Peak } \\
\text { Frequency (Hz) }\end{array}$ & $\begin{array}{c}\text { Random } \\
\text { 130 lb-rms Peak } \\
\text { Frequency (Hz) }\end{array}$ & $\begin{array}{c}\text { Random } \\
\text { 200 Ib-rms Peak } \\
\text { Frequency (Hz) }\end{array}$ & $\begin{array}{c}\text { 50 vs. 200 lb-rms } \\
\text { Percent } \\
\text { Difference (\%) }\end{array}$ \\
\hline $2^{\text {nd }}$ bending Y-direction & 1.0605 & 1.0586 & 1.0586 & -0.18 \\
\hline $2^{\text {nd }}$ bending Z-direction & 1.1953 & 1.1953 & 1.1855 & -0.82 \\
\hline $3^{\text {rd }}$ bending Y-direction & 3.4649 & 3.4590 & 3.4531 & -0.34 \\
\hline $3^{\text {rd }}$ bending Z-direction & 3.6856 & 3.6816 & 3.6738 & -0.32 \\
\hline $4^{\text {th }}$ bending Y-direction & 4.6133 & 4.6113 & 4.6074 & -0.13 \\
\hline $4^{\text {th }}$ bending Z-direction & 4.7910 & 4.7832 & 4.7832 & -0.16 \\
\hline
\end{tabular}


The sine sweep test data was also used to investigate modal frequency shifts for the $2^{\text {nd }}$ and $3^{\text {rd }}$ modes at higher force levels than the random test. The test data was processed by taking a single Discrete Fourier Transform of the entire time history for each channel and computing the frequency response functions by the simple ratio of the acceleration spectra over the force spectrum ${ }^{10}$. The resulting peak frequencies are listed in Table 3, which show frequency shifts less than 1.2\% from 50 to $200 \mathrm{lb}$-peak. Again, the greatest frequency shift was observed for the $2^{\text {nd }}$ bending mode in the Z-direction, while the other bending modes did not shift by more than $0.18 \%$.

Table 3. Peak Frequency Changes for Sine Sweep Excitation

\begin{tabular}{|c|c|c|c|c|}
\hline Mode & $\begin{array}{c}\text { Sweep Up } \\
50 \text { lb-pk Peak } \\
\text { Frequency (Hz) }\end{array}$ & $\begin{array}{c}\text { Sweep Up } \\
100 \text { lb-pk Peak } \\
\text { Frequency (Hz) }\end{array}$ & $\begin{array}{c}\text { Sweep Up } \\
200 \text { lb-pk Peak } \\
\text { Frequency (Hz) }\end{array}$ & $\begin{array}{l}50 \text { vs. } 200 \text { lb-pk } \\
\text { Percent } \\
\text { Difference (\%) }\end{array}$ \\
\hline $2^{\text {nd }}$ bending $Y$-direction & 1.0527 & 1.0527 & 1.0508 & -0.18 \\
\hline $2^{\text {nd }}$ bending Z-direction & 1.1836 & 1.1797 & 1.1699 & -1.2 \\
\hline $3^{\text {rd }}$ bending $Y$-direction & 3.4600 & 3.4590 & 3.4590 & -0.03 \\
\hline $3^{\text {rd }}$ bending Z-direction & 3.6777 & 3.6797 & 3.6729 & -0.13 \\
\hline
\end{tabular}

A sample time history from the $3^{\text {rd }}$ free decay test of the $1^{\text {st }} Y$-direction bending mode is shown in figure 14. The time history was low pass filtered with a $1.0 \mathrm{~Hz}$ Bessel filter in order to clean up the peaks, but this had little effect on the overall trends in the time history data. A plot of the natural logarithm of the peaks from the time history versus peak number indicated that the damping was linear over the tested amplitude range because the slope of the line is proportional to the damping ratio ${ }^{11}$. The resulting damping ratios from the free decay tests are listed in Table 4. Additionally, the average damped natural frequency of the decay was easily estimated from the time history data. This frequency was used along with the peak acceleration amplitudes to approximate the displacement of the top of the flight test vehicle during the test.

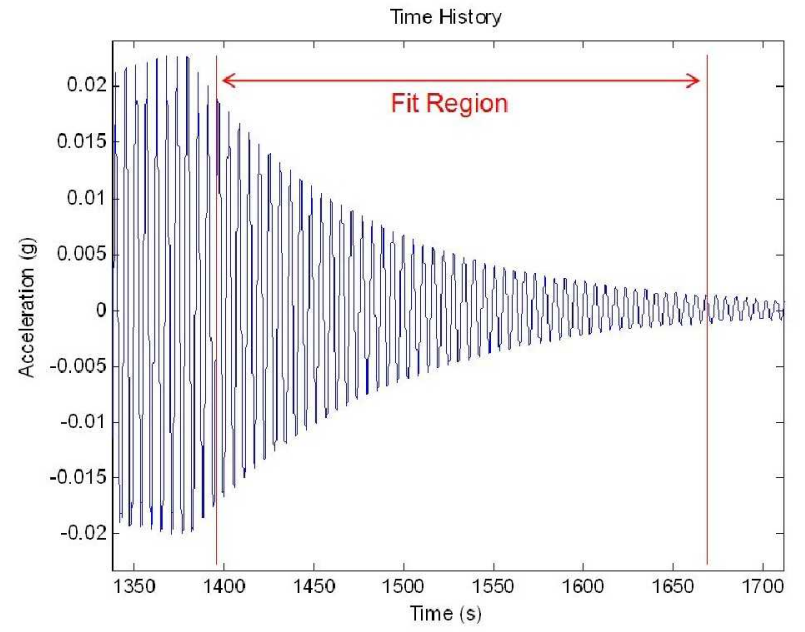

Figure 14. Y-direction free decay test data from the top of the flight test vehicle

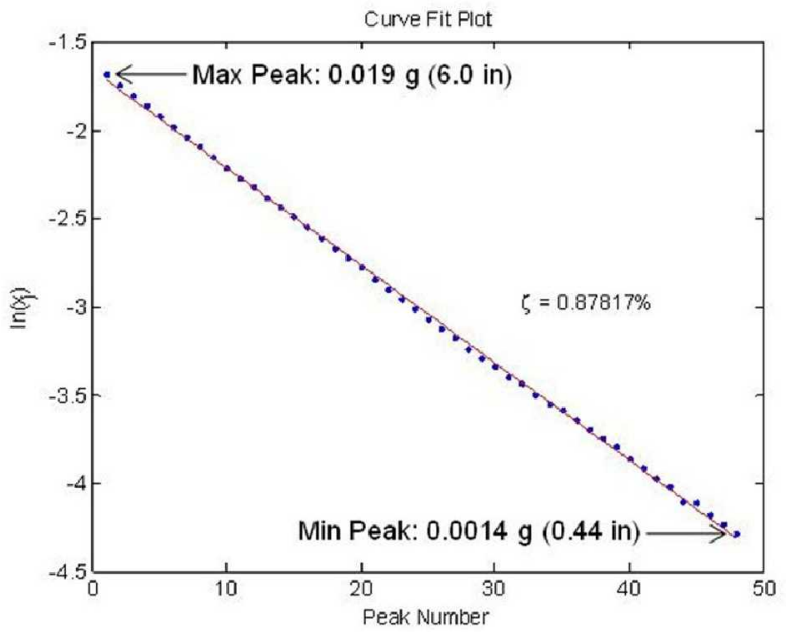

Figure 15. Linearity of damping from Y-direction free decay test data 
Table 4. Free Decay Test Results from the Flight Test Vehicle Modal Test

\begin{tabular}{|c|c|c|c|c|c|c|}
\hline \multirow{2}{*}{ Mode } & Decay \# & $\begin{array}{c}\text { Maximum } \\
\text { Unfiltered } \\
\text { Amplitude } \\
\text { During } \\
\text { Push (in) }\end{array}$ & $\begin{array}{c}\text { Maximum } \\
\text { Unfiltered } \\
\text { Amplitude at } \\
\text { Start of } \\
\text { Decay (in) }\end{array}$ & $\begin{array}{c}\text { Maximum } \\
\text { Fit } \\
\text { Amplitude } \\
\text { (in) }\end{array}$ & $\begin{array}{c}\text { Free Decay } \\
\text { Frequency } \\
\text { (Hz) }\end{array}$ & Damping (\%) \\
\hline \multirow{3}{*}{$1^{\text {st }}$ bending Y-direction } & 1 & 5.40 & 4.90 & 4.75 & 0.1776 & 0.81 \\
\cline { 2 - 7 } & 2 & 7.80 & 7.80 & 6.78 & 0.1764 & 0.88 \\
\cline { 2 - 7 } & 3 & 8.28 & 8.28 & 5.98 & 0.1764 & 0.88 \\
\hline \multirow{3}{*}{$1^{\text {st } \text { bending Z-direction }}$} & 1 & 6.85 & 6.85 & 5.55 & 0.2149 & 0.45 \\
\cline { 2 - 7 } & 2 & 8.29 & 8.29 & 6.45 & 0.2142 & 0.43 \\
\cline { 2 - 7 } & 3 & 7.82 & 7.82 & 6.97 & 0.2145 & 0.44 \\
\hline $2^{\text {nd }}$ bending Y-direction & 1 & 0.0908 & 0.0793 & 0.0392 & 1.056 & 0.23 \\
\hline
\end{tabular}

Final modal parameters from the modal test were estimated using different methods by several analysts. Most analysts used the $\mathrm{H} 1$ estimates for random excitation with industry standard parameter estimation routines. One more rigorous approach was used to try and improve the $1^{\text {st }}$ bending estimates using data from the $200 \mathrm{lb}-$ rms random test. The frequency response functions for this curve fit were processed in a different manner than the processing method used during the data acquisition. The time histories from the accelerometers and Integrated Electronics Piezo Electric (IEPE) load cell signals with biases removed were processed by taking cyclic averages, then applying a Hanning window and processing the blocks with a $75 \%$ overlap. The Hv estimator was used to compute the frequency response functions. The curve fit used the PolyMAX algorithm ${ }^{12}$, and only the $Y$ and Z-axis measurements were included during the pole estimation process. The results from this method and several others are included in Table 5, which summarizes the final target modal parameter estimates for the Ares I-X flight test vehicle on the Mobile Launcher Platform. Because of the issues with the $1^{\text {st }}$ bending modes in the random datasets, the frequency and damping estimates for these modes were taken from the free decay data. Free decay data was also used in addition to the random data to estimate the damping of the $2^{\text {nd }}$ bending modes. Overall, the data compiled from several different analysts, parameter estimation routines, and datasets is very consistent. A comparison of these average measured frequencies to the predicted frequencies is listed in Table 6. The comparison shows that the majority of the measured frequencies were within $5 \%$ of predictions, with one exception at $6.4 \%$ for the $3^{\text {rd }}$ bending mode in the Y-direction. More information about the use of the measured data in the post-test analysis is included in a companion paper?.

Table 5. Summary of Modal Parameter Estimates from Ares I-X Flight Test Vehicle Modal Test

\begin{tabular}{|c|c|c|c|c|c|c|c|}
\hline Mode & $\begin{array}{c}\text { Average } \\
\text { Freq } \\
(\mathbf{H z})\end{array}$ & $\begin{array}{c}\text { STD } \\
\text { Freq } \\
(\mathbf{H z})\end{array}$ & $\begin{array}{c}\text { Average } \\
\text { Damp } \\
(\%)\end{array}$ & $\begin{array}{c}\text { STD } \\
\text { Damp(\%) }\end{array}$ & $\begin{array}{c}\text { Min } \\
\text { Damp(\%) }\end{array}$ & $\begin{array}{c}\text { Max } \\
\text { Damp } \\
(\%)\end{array}$ & Data Source \\
\hline \hline $\begin{array}{c}\text { 1st Bending Y } \\
\text { direction }\end{array}$ & 0.178 & 0.002 & 0.848 & 0.038 & 0.81 & 0.88 & $\begin{array}{c}\text { only free-decay } \\
\text { data }\end{array}$ \\
\hline $\begin{array}{c}\text { 1st Bending Z } \\
\text { direction }\end{array}$ & 0.213 & 0.002 & 0.433 & 0.017 & 0.41 & 0.45 & $\begin{array}{c}\text { only free-decay } \\
\text { data }\end{array}$ \\
\hline $\begin{array}{c}\text { 2nd Bending Y } \\
\text { direction }\end{array}$ & 1.06 & 0.001 & 0.290 & 0.034 & 0.23 & 0.31 & $\begin{array}{c}\text { free-decay and } \\
\text { random }\end{array}$ \\
\hline $\begin{array}{c}\text { 2nd Bending Z } \\
\text { direction }\end{array}$ & 1.19 & 0.004 & 0.372 & 0.081 & 0.25 & 0.46 & $\begin{array}{c}\text { free-decay and } \\
\text { random }\end{array}$ \\
\hline $\begin{array}{c}\text { 3rd Bending Y } \\
\text { direction }\end{array}$ & 3.46 & 0.003 & 0.483 & 0.036 & 0.43 & 0.51 & random data \\
\hline $\begin{array}{c}\text { 3rd Bending Z } \\
\text { direction }\end{array}$ & 3.65 & 0.002 & 0.388 & 0.015 & 0.37 & 0.40 & random data \\
\hline $\begin{array}{c}\text { 4th Bending Y } \\
\text { direction }\end{array}$ & 4.61 & 0.001 & 0.175 & 0.006 & 0.17 & 0.18 & random data \\
\hline $\begin{array}{c}\text { 4th Bending Z } \\
\text { direction }\end{array}$ & 4.78 & 0.003 & 0.243 & 0.010 & 0.23 & 0.25 & random data \\
\hline
\end{tabular}


Table 6. Comparison of Predicted and Measured Frequencies

\begin{tabular}{|c|c|c|c|}
\hline Mode & $\begin{array}{c}\text { Predicted } \\
\text { Freq (Hz) }\end{array}$ & $\begin{array}{c}\text { Measured } \\
\text { Freq (Hz) }\end{array}$ & $\begin{array}{c}\text { Percent } \\
\text { Difference } \\
(\%)\end{array}$ \\
\hline 1st Bending Y direction & 0.176 & 0.178 & 1.1 \\
\hline 1st Bending Z direction & 0.216 & 0.213 & -1.4 \\
\hline 2nd Bending Y direction & 1.02 & 1.06 & 3.7 \\
\hline 2nd Bending Z direction & 1.17 & 1.19 & 2.0 \\
\hline 3rd Bending Y direction & 3.25 & 3.46 & 6.4 \\
\hline 3rd Bending Z direction & 3.50 & 3.65 & 4.2 \\
\hline 4th Bending Y direction & 4.78 & 4.61 & -3.6 \\
\hline 4th Bending Z direction & 4.84 & 4.78 & -1.2 \\
\hline
\end{tabular}

\section{CONCLUSIONS}

The target modal parameters for the Ares I-X flight test vehicle were obtained using both free decay and random datasets. The $1^{\text {st }}$ bending mode pair was difficult to curve fit from the random data due to inadequate response measurements at lower frequencies that split the peaks of the frequency response functions, so the natural frequencies and damping ratios were determined from free decay data. The $2^{\text {nd }}$ through $4^{\text {th }}$ bending modes were well defined in the random data. Additionally, sine sweep tests were performed on the $2^{\text {nd }}$ and $3^{\text {rd }}$ bending modes to investigate frequency nonlinearities. Results from multiple levels of random and sine sweep testing indicated linear frequency behavior of the modes, with maximum frequency shifts of $1.2 \%$ for quadruple the force levels. Overall, the modal test successfully identified the modal parameters for all of the targeted bending modes of the Ares I-X flight test vehicle, and the measured modal frequencies were in good agreement with pre-test predictions.

\section{REFERENCES}

1. Buehrle, R.D., et. al., "Ares I-X Launch Vehicle Modal Test Overview," Proceedings of IMAC XXVIII, February 2010.

2. Kennedy Space Center Media Gallery, http://mediaarchive.ksc.nasa.gov/search.cfm?cat=166, October 2009.

3. Buehrle, R. D.; Templeton, J. D.; Bartolotta, P. A.; Reaves, M. C.; Horta, L. G.; Parks, R. A.; Lazor, D. R.; Gaspar, J. L.: Ares I-X Flight Test Vehicle: Stack 5 Modal Test NASATM-2010-216183, January 2010.

4. Buehrle, R. D.; Templeton, J. D.; Bartolotta, P. A.; Reaves, M. C.; Horta, L. G.; Parks, R. A.; Lazor, D. R.; Gaspar, J. L.: Ares I-X Flight Test Vehicle: Stack 1 Modal Test, NASA/TM-2010-216210, March 2010.

5. Buehrle, R. D.; Templeton, J. D.; Bartolotta, P. A.; Reaves, M. C.; Horta, L. G.; Parks, R. A.; Lazor, D. R.; Gaspar, J. L.: Ares I-X Flight Test Vehicle Modal Test, NASA/TM-2010-216182, January 2010.

6. Elliott, A.S., and Richardson, M. H., "Virtual Experimental Modal Analysis (VEMA)," Proceedings of IMAC XVI, February 1998.

7. Ewins, D.J., Modal Testing: Theory, Practice and Application, $2^{\text {nd }}$ ed., Research Studies Press Ltd., pp. 231 $234,2000$.

8. Lollock, J.A., "The Effect of Swept Sinusoidal Excitation on the Response of a Single-Degree-of-Freedom Oscillator," Proceedings of the $43^{\text {rd }}$ AIAA/ASME/ASCE/AHS/ASC Structures, Structural Dynamics and Materials Conference, April 2002.

9. Horta, L. H., et. al., "Finite Element Model Calibration Approach for Ares I-X," Proceedings of IMAC XXVIII, February 2010. 
10. Orlando, S., Peeters, B., and Coppotelli, G., "Improved FRF Estimators for MIMO Sine Sweep Data," Proceedings of the ISMA 2008 International Conference on Noise and Vibration Engineering, Leuven, Belgium, September 2008.

11. Meirovitch, Fundamentals of Vibrations, McGraw-Hill, pp. 94 - 98, 2001.

12. Peeters, B, et. al., "The PolyMAX Frequency Domain Method: A New Standard for Modal Parameter Estimation?" Journal of Shock and Vibration, Vol. 11, pp. $395-409,2004$. 